\title{
A HISTORY OF LOWER-INCOME COUNTRIES IN (AND OUT OF) GLOBAL TAX GOVERNANCE
}

\section{Actually if I had a choice I would scrap all double taxation treaties, because that was really a concept put there by developed countries to help their multinational companies.}

-Former tax treaty negotiator and Commissioner of Internal Revenue, Asian country

While the tax treaties that are the focus of this book range from those signed in the 2010s to some that are fifty years old, the models on which they are all based date from earlier still. It was in the 1920s and 1930s that the basic design of the international tax regime was laid out, combining the decentralized, bottom-up approach of hard-law bilateral treaties with top-down soft-law standardization through multilateral models. ${ }^{1}$ Key concepts that now constrain countries' ability to tax multinational companies were also developed at this time, finally set in stone with the creation of the OECD model treaty in 1963. Throughout this century of negotiations, the tension between capital-importing lower-income countries and capital-exporting higher-income countries has been a consistent theme. Yet the center of gravity of the regime we have today, even taking into account the UN model treaty's greater emphasis on lower-income countries' taxing rights, is much closer to the position articulated by higher-income countries than by lower-income countries.

This chapter reviews the historical record, combining original archival research with existing accounts to give a political economy perspective on a story that is familiar to tax history scholars. It demonstrates that higher-income countries' domination of the international tax regime results from their stronger preference for cooperation among themselves, which drove repeated and insurmountable first-mover advantages. Today's international tax institutions were not primarily designed for lower-income countries but by and for higher-income ones. They resemble those countries' own tax systems and a consensus that formed among a transnational community of experts from the Global North. 
Higher-income countries began to introduce the corporate income tax in its modern form in the early twentieth century. ${ }^{2}$ Since business activities were already somewhat globalized at this time, this new tax was designed by states from the beginning bearing in mind the effects of its interaction with other states' tax systems. Most states wanted to be able to tax foreign companies' earnings within their borders, as well as the worldwide profits of their own multinationals, a situation that was not tenable if every state did it in an uncoordinated fashion. Consequently, soon after the First World War, states began to work together through the League of Nations to construct a set of international norms that shaped their domestic tax laws as well as the tools of cooperation. ${ }^{3}$ While some lower-income countries were present in the League they joined its tax discussions late and were unable to influence them. In the 1960s, it was again a group of higher-income countries that consolidated the earlier work into the OECD's model bilateral tax convention. The growing pressures from globalization since then have transformed and intensified the original conflicts, forcing OECD states to elaborate an increasingly complex and detailed global tax regime. Their tax systems have converged on a common approach formulated over decades of collective experimentation and negotiation.

Although they did not design it, lower-income and transition countries began to be absorbed into this system from the 1970s, concluding more and more bilateral tax treaties and developing their tax codes on the basis of OECD tax concepts and standards, some of which they adopted wholesale. ${ }^{4}$ Whereas the domestic tax laws of higher-income countries were mutually co-constituted with the international regime, for most lower-income countries the traffic has been one-way. Their very identities as fiscal states - from the purpose and definition of corporate tax to the fiscal state's responsibilities toward its taxpayers-have not formed in isolation but as participants on the outer edges of this regime. In most cases, elements of their tax systems that were inconsistent with OECD standards have been reformed to bring them in line with international norms, or at least overridden by bilateral tax treaties.

To tell this story, this chapter begins with the emergence of the "tax state" itself, exploring the connection among statehood, sovereignty, and taxation. It then considers how the tax state in lower-income countries higher-income differently, as much a product of exogenous influences as endogenous social forces. The rest of the chapter traces the development of the institutions of global tax governance from the League of Nations through to the OECD, illustrating how the different phases of cooperation established and consolidated higher-income countries' first-mover advantage as rule makers, in contrast to lower-income countries, which arrived later and became rule takers. In particular, the OECD's model bilateral tax convention became both the most widespread template for bilateral nego- 
tiations and the most powerful focal point around which the expectations of participants in the international tax regime have converged.

\section{Prehistory}

The history of taxation is intertwined with the history of the modern state itself. As Rudolf Goldscheid asserted, "The origin of the state lies in association for the purposes of defence and to meet common fiscal needs." 5 His fellow "fiscal sociologist" Joseph Schumpeter, in the first manifesto on the subject, Crisis of the Tax State, asserted that "the fiscal history of a people is above all an essential part of its general history," emphasizing that taxation not only was a useful lens through which to view political and social events but also played a causal role in those events. ${ }^{6}$ While Schumpeter and Goldscheid may have been the first to explicitly emphasize the fiscal part of their story, others before them had recognized the importance of taxation for any understanding of the state. According to Edmund Burke, writing about postrevolutionary France, "The revenue of the state is the state. In effect all depends upon it, whether for support or for reformation."7

Schumpeter's argument ran as follows. As warfare between princedoms led more and more European princes to face financial difficulties in the fourteenth and fifteenth centuries, they turned to the estates they governed to finance the war effort, and in doing so a public financial realm came into being, separate from the prince's private finances: the tax state. Writing at the end of the First World War, Schumpeter traced the development of the Austrian tax state but argued that it faced a crisis, burdened by war debts and reaching the limit of its taxing capacity as it struggled to repay them. ${ }^{8}$ Others, writing subsequently, have characterized the tax state's evolution into the "fiscal state," which is distinguished by its ability to borrow sustainably on the strength of its reliable revenue stream, and hence its greater financial capacity to react to wars and other emergencies. ${ }^{9}$

The "militarist" fiscal sociology account is found across many descriptions of state development. In Norbert Elias's history of state formation, the modern state is characterized by two mutually reinforcing monopolies: military force coerces the payment of taxation, which in turn funds military force. ${ }^{10}$ Charles Tilly expanded on Elias's ideas as follows: "Where did the money [for warfare] come from? In the short run, typically from loans by capitalists and levies on local populations unlucky enough to have troops in their vicinity. In the long run, from one form of taxation or another." 11

Income tax, the focus of this book, was first introduced in the UK in 1799 to fund the war with Napoleonic France, and continued to be tied explicitly to war efforts right through to the First World War. ${ }^{12}$ In the United States, too, federal 
income tax was first levied by Congress in 1861 to fund its efforts in the civil war. ${ }^{13}$ Wars also played a role in the introduction of income tax in France and Austria. ${ }^{14}$

The next stage of the account runs as follows. Extending the revenue base to more powerful, wealthy citizens who up to that point may have been insulated from the burden of coercive taxation created two imperatives: the establishment of administrative institutions to collect and manage the revenue separately from the prince's private household, and the formation of a social contract with these new taxpayers. ${ }^{15}$ To collect taxes from these groups, the ruler relied on their consent, a shift characterized by Mick Moore as going from "coercive" to "contractual" taxation. ${ }^{16}$ In sixteenth-century Austria, for example, Schumpeter describes how the estates' contributions to the defense of the princedoms came with an expectation of some capacity to influence both the distribution of the tax liability and the use to which the tax revenue was put. ${ }^{17}$ Evidence shows that a higher tax burden on an elite leads to policies that favor it, and a higher tax burden in general leads to a more democratic or liberal polity: "In the long run, democratisation only occurs when rulers come to rely on citizen compliance for their means of rule," according to Tilly. ${ }^{18}$

The militarist account is only one lens through which to view the development of the fiscal state. Others have situated it within the deterministic sweep of economic and social modernization, the emphasis of institutionalist theory on path dependence, or have emphasized the role of elite and, later, popular consent. ${ }^{19}$ The "new fiscal sociologists" argue that "taxation is central not only to the state's capacity in war, but in fact to all social life." ${ }^{20}$ Because taxation is integral to the development of state-citizen relations, the fiscal component of sovereignty is an essential part of any story of the development of international relations, especially one that recognizes that both "war made the state, and the state made war." 21 The state needs tax revenue to safeguard the security of its citizens, but the act of taxation is also part of the social construction of the state itself, of its sovereignty within a given area.

Fiscal sovereignty is complicated, however, by the ability of economic factors to cross borders. If states attempt to exercise it in conditions of anarchy-without cooperation - it may be self-defeating. Without cooperation, overlapping claims to tax the same income will create onerous double taxation that deters trade and investment. Worse still, taxpayers may respond to a high tax burden in one country by moving to another or by placing their wealth in another jurisdiction, beyond the reach of their home state's administrative capacity. According to Peggy Musgrave, author of several seminal works in the tax literature interrogating this question, "It is likely that in the absence of cooperative agreements . . . countries will exercise their entitlements in a way to serve their national interests and that 
these interests may conflict with each other and with standards of inter-nation equity and allocative efficiency." 22

Musgrave forms part of a long tradition of advocates for a formal international tax authority, whose proposals have failed to gain traction because of the strength of feeling about fiscal sovereignty. ${ }^{23}$ Nonetheless, states have chosen to establish some degree of cooperation, because an anarchic "state of nature" would limit their ability to exercise their fiscal sovereignty in practice.

Indeed, it is hard to sustain a linear view in which national tax laws precede international cooperation, since the two have coevolved from the beginning. We are in a Waltzian world. ${ }^{24}$ If economic factors can cross borders, it is hard to think that an absolute notion of fiscal sovereignty ever made sense. ${ }^{25}$ As Allison Christians writes, "If tax sovereignty means anything, perhaps it is the idea that governments have a non-exclusive right to decide through political means whether and how to tax whatever activity occurs within their territories and whomever can be considered to be their 'people', and that they recognize a reciprocal right in all other states." 26

When developing their own international tax systems (that is, their domestic laws as they pertain to multinational taxpayers) in the interwar years, states were already constrained by the way in which their laws might interact with those of other countries, and this was one of the main motivating factors behind their first steps at international tax cooperation. ${ }^{27}$ Western states made explicit efforts to copy each other's laws at this time, while many lower-income countries emerged from colonialism with a facsimile of the colonizer's tax system. ${ }^{28}$

\section{The Special Case of Lower-Income Countries}

The development of the tax state in postindependence lower-income countries was somewhat different from the Eurocentric model. In part, this was a timing issue: when the contours of the international tax regime were put in place, lowerincome countries were still under colonial rule, or had not yet been penetrated by significant amounts of foreign investment. On the one hand, the financing of a war effort against an external aggressor was not generally available as a pretext for asking citizens to make a greater tax contribution. ${ }^{29}$ On the other hand, most lower-income states' fiscal situations were-and are-heavily influenced by external actors: tax systems were inherited from colonial governments and further influenced by donors, lenders, and technical assistance providers; overseas aid provided an additional source of revenue that changed leaders' incentives to raise 
and spend revenue in particular ways; tax levied on (and collected by) multinational investors, especially in those countries with extractive industries, made up a much larger share of tax revenue than in higher-income countries. ${ }^{30}$

Newly independent lower-income countries inherited tax systems from their colonial powers that shaped their legal codes, administrative structures, and even their ability to raise revenue. As Thandika Mkandawire demonstrates, "the end of colonialism left an institutional and infrastructural residue that still plays a major role in the determination of tax policies and the capacity to collect tax." 31 Victor Thuronyi identifies eight "families of income tax laws," traceable mostly to former empires. ${ }^{32}$ Mick Keen notes that francophone African countries today still perform worse than their Anglophone continental neighbors at raising tax revenue. ${ }^{33}$ Many countries also inherited tax treaties that had been put in place within the colonial system.

Since that initial starting point, probably an even greater influence on the design of lower-income countries' tax systems has come from thousands of technical assistance missions. In 1989, the economist Malcolm Gillis estimated in an edited volume written by many of those most experienced in technical assistance that "there have been perhaps one hundred identifiable attempts at major tax reform in developing nations since 1945." ${ }^{44}$ Indeed, the history of such missions predates many lower-income countries' independence and can be traced to the "Shoup Mission" of 1949-50. A group of seven US academics led by the economist Carl Shoup are credited with the design of Japan's modern tax system, including the introduction of corporate income tax. ${ }^{35}$ With the IMF and World Bank's emphasis on structural adjustment from the 1980s onward, tax reform advice and conditionality started to crystallize around a set of recommendations consistent with the "Washington Consensus" described by John Williamson. Tax reform was one of Williamson's original ten points, and his original essay noted "a very wide consensus" around the principle "that the tax base should be broad and marginal tax rates should be moderate." ${ }^{36}$ Miranda Stewart describes the associated policies as follows: "The contemporary tax reform 'package' intended to achieve these goals includes a single-rate, broad-based VAT [value-added tax] to replace older-style sales taxes; a low-rate, broad-based corporate and personal income tax; the goal of tax 'neutrality' with respect to different investments and activities; and the gradual reduction and eventual elimination of import and export tariffs." ${ }^{37}$

Thus, while countries of the Global South no doubt looked to each other for inspiration and experience when building their tax systems, lower-income countries' tax systems have consistently been built with input from experts from the Global North. At times they have been imposed, whether through colonial measures or economic conditionality. Lower-income countries start from a position 
of learning from others. Chapter 4 considers how technical assistance in the area of international taxation contributed to the emergence of lower-income countries' tax treaty networks.

A second difference between higher-income and lower-income countries concerns the incentives their political leaders face. Higher-income countries introduced income taxation at a point where they urgently needed the public funds. For the governments of many lower-income countries, alternative sources of revenue can distort this incentive. There is some evidence, for example, that overseas development assistance (foreign aid) can crowd out tax revenue raising, since governments have a smaller incentive to impose tax costs on their citizens; when segmented, the effect appears to apply to grants but not loans, which must ultimately be repaid through tax revenue. ${ }^{38}$ Similarly, in resource-rich lower-income countries, nontax revenue earned by the government from the extraction of oil, gas, or minerals can have a similar effect, ${ }^{39}$ part of a broader "political resource curse" through which natural resource revenues are thought to have a detrimental effect on political institutions. ${ }^{40}$

Third, lower-income countries' dependence on foreign investment places them in a unique situation in comparison with higher-income countries. They are "dependent market economies," in which capital is primarily foreign owned, ${ }^{41}$ and there is a lower capacity to raise revenue through the taxes used by higherincome countries: a much smaller proportion of their population is in formal employment and earning enough to pay personal income tax, the main source of revenue in higher-income countries. ${ }^{42}$ Low-income countries collect taxes amounting to 18 percent of GDP, compared with 32 percent in high-income countries, yet both groups collect taxes from companies amounting to around 3 percent of GDP. The result is that one tax dollar in seven raised by lower-income countries comes from taxes on businesses, as compared with one in eleven for high-income countries. ${ }^{43}$

Lower-income countries often have higher tax rates than higher-income countries, but their tax systems are riddled with tax holidays and other incentives and are less well defended against tax avoidance by multinationals. The former problem comes about precisely because they are heavily dependent on foreign capital to enable them to exploit their abundant labor and land. The governments of lower-income countries are much more sensitive to the structural power of foreign capital, to the threat of discouraging inward investment through their tax systems. Indeed, a proliferation of tax incentives illustrates that they have been engaged in a race to the bottom since soon after independence, originally encouraged, but now discouraged in vain, by technical advisers. ${ }^{44}$ The form of this competition, however, is influenced by the tax systems of higher-income countries. ${ }^{45}$ In particular, as the latter have moved toward systems that exempt foreign 
income from further taxation at home, multinational investors have become more sensitive to changes in effective tax rates in their host countries.

In the story that follows, therefore, we must separate the rule makers and the rule takers. For the major players in the League of Nations, the Organisation for European Economic Cooperation (OEEC; the predecessor of the OECD) and now the OECD's fiscal committees, participation in the international tax regime has meant shaping a set of rules that regulate the interface between tax systems as they develop, adapting international rules to their domestic laws and vice versa. These countries learned from their own experiences and those of others, and shaped national and international tax rules accordingly. In contrast, for lower-income countries, those same rules came bundled in a consensus package of tax advice, broadcast to them through successive waves of colonization, technical assistance missions, conditionality, and development fads. Throughout the twentieth century, with a few exceptions, lower-income countries were purely in receiving mode when it came to international tax norms. Yet the rules governing the taxation of multinational companies are, if anything, more important to lower-income countries, because of their reliance on foreign capital and the disproportionate role of business taxation in their tax mixes. As we shall see, however, despite the differences in the interests of capital-importing and capital-exporting nations being fairly clear from early on, international tax standards represent the interests of the latter.

\section{The League of Nations Era}

As income tax systems became formalized in the Western world after the First World War, and rates rose to pay for the war effort, double taxation and tax evasion soon began to create problems for taxpayers and tax authorities. An International Chambers of Commerce (ICC) resolution in 1920, one of a series addressed to the League, called for "prompt agreement between the Governments of the Allied countries in order to prevent individuals or companies from being compelled to pay a tax on the same income in more than one country." 46 When the League's Provisional Economic and Financial Committee was created in October 1920, double taxation was included within its mandate, alongside matters such as postwar financial reconstruction. A Fiscal Committee in its own right was created in 1929.

During this period in which national and international tax regimes were simultaneously in flux, there were no existing rules to constrain the architects of the international tax regime. A handful of bilateral tax treaties had been signed, giving states some examples to work with, but there was no international con- 
sensus. To take a historical institutionalist approach, this was a critical juncture in which decisions with long-term implications were made and a few influential individuals were able to shape the design of a regime that has become notoriously sticky. ${ }^{47}$ Accounts of the league's deliberations, contemporaneous ones by participants and observers as well as subsequent analysis by historians, emphasize the role of personalities and personal positions, both in creating conflict and in helping to overcome differences between national interests. ${ }^{48}$ Edwin Seligman and Thomas Adams, for example, were both experts nominated by the United States at different times, and both were influential in the design of the US international tax system; they disagreed with each other on the source and residence matter. ${ }^{49}$ Adams took a liberal view whereby more source taxation was in the interest of the United States because it would build a more inclusive international tax regime, which brought him into conflict with the staunchly residence-based views of his British counterpart, Percy Thompson. ${ }^{50}$

The central distributional dispute between higher-income and lower-income countries concerns the right to tax at "source," where a business makes its profits, versus at "residence," where it has its headquarters. Once the differences between tax systems and economic positions are taken into account, it is a thorny matter to resolve among any group of countries. As Thomas Rixen suggests, even OECD states cannot reach agreement on distributional questions in a multilateral setting, so they develop multilateral tools that will act as focal points for bilateral negotiations in which those distributional questions are resolved. ${ }^{51}$ These tools, beginning with the first League of Nations models and running through to the present day OECD model and associated guidelines, are not neutral with respect to distributional questions, however. Source versus residence has been a constant theme in the development of the international tax regime since the 1920s.

The League proceeded through the drafting of a series of reports, beginning with the 1925 report of a Committee of Technical Experts to the Financial Committee, and concluding with the Fiscal Committee's tenth report in 1946, which also incorporated the influential London Draft. A brief examination of the countries participating in this drafting and the exchanges on the source-residence debate will illustrate the general orientation of the considerations. In 1923-25, during the drafting of the 1925 report, seven countries participated. Although these were all higher-income countries, source and residence was the main bone of contention between the combative British representative, Percy Thompson of the Board of Inland Revenue, and the others from continental Europe. The UK was still at this point an exporter of capital to mainland Europe, much of which was in heavy debt and reconstruction following the war, and thus Thompson preferred an emphasis on residence taxing rights, especially for the UK's general income tax. The other participants were keen to retain the UK's support, as a 
"great economy," and so the 1925 report, which included a number of resolutions establishing general principles on double taxation, had a stronger residence orientation than that preferred by the majority. ${ }^{52}$

When five new countries joined the committee to draft a model convention on the basis of the 1925 report, the new Argentinian and Venezuelan members quickly raised their concern that the resolutions of the 1925 report on income tax would disadvantage their countries, arguing for more source and less residence taxation. ${ }^{53}$ But it was too late, and they were outnumbered. Sunita Jogarajan, in her exhaustive study of the records of these discussions, concludes that "the compulsion to follow the 1925 report significantly reduced the influence of ... the representatives from 'developing countries.' 54 The pattern occurred again when the franchise was opened to all countries in 1928: Bulgaria and Spain criticized what they regarded as an antisource bias in the $1927 \mathrm{draft}$ convention, while Poland and South Africa took a more favorable view, citing investment promotion. ${ }^{55}$ The momentum behind the existing draft prevented this discussion from influencing the outcome to any great extent, and the 1928 report, which incorporated three very similar model conventions, set the precedent from that time onward.

Numerous tax treaties were concluded during the 1930s and early 1940s, creating a desire on the part of the Fiscal Commission to revisit the 1928 models in the light of recent negotiating experience. While the European countries that had dominated the initial deliberations were embroiled in the Second World War, the Western Hemisphere continued to work. At a meeting held in Mexico in 1943, Latin American countries along with the United States and Canada agreed to the "Mexico Draft" convention, which drew on the 1928 report, but gave much stronger taxing rights to source countries. Following the end of the Second World War, and the conclusion of a treaty between the United States and the UK that effectively brokered a consensus between them, the Fiscal Commission held its final session at Somerset House in London. The meeting, which was dominated by European countries, agreed a new London Draft convention. The commission's report presents the Mexico and London Drafts side by side and states that, "virtually, the only clauses where there is an effective divergence between the views of the 1943 Mexico meeting and those of the 1946 London meeting are those relating to the taxation of interest, dividends, royalties, annuities and pensions." 56 These were no small disagreements, and the two models adopted diametrically opposed positions as to, for example, which country should be entitled to tax the interest payments on a cross-border loan. The commission suggested that "the work done both in Mexico and in London could be usefully reviewed and higherincome by a balanced group of tax administrators and experts from both capital- 
importing and capital-exporting countries and from economically-advanced and less-advanced countries, when the League work on international tax problems is taken over by the United Nations." 57

While the United Nations did indeed take up work on double taxation within a "balanced group" of technical experts, this work did not progress very far. By the UN Fiscal Commission's second session in 1949, Cold War divisions had already begun to characterize its deliberations on double taxation treaties. According to the British delegate at the meeting, the Soviet, Ukrainian, and Czechoslovak members "took exception to international action in this field on the grounds that it represented pressure on the under-developed countries to the advantage of highly developed countries. ${ }^{58}$ By its third session, a divide had also opened between higher-income and lower-income countries on the nowtraditional source and residence lines. The International Civil Aviation Organisation (ICAO) had brought a proposal for reciprocal exemption of airlines, by which companies operating flights would be exempt from taxation in the countries to which they fly, paying it only in the country where they were based. India, Pakistan, Venezuela, and Cuba raised objections, pointing out that if only one country signing the treaty had an airline, "reciprocal exemption is quite unfair." 59 The ICAO proposal, which was consistent with the treaty policy of countries with their own airlines, fell after a vote in which the lower-income countries were joined by the Soviet group. ${ }^{60}$ This compares to the reciprocal exemption of shipping companies, which had been comfortably agreed to by the higher-income-country-dominated League of Nations.

By the time the commission's work reached the Economic and Social Council (ECOSOC) in 1951, it appears to have run out of steam. Alexander Morosov, the Russian participant (also its representative on the Fiscal Commission itself), expressed his familiar objection that the commission's work on double taxation "was in reality intended to promote economic conditions favourable to the activities of British and American monopolies." He concluded that the commission "was engaged in futile operations, and that it was therefore useless to keep it in existence." ${ }^{61}$ According to his Polish counterpart, "The majority of the Commission had, by certain of the recommendations adopted by that body, tried to exploit the authority of the Economic and Social Council to relieve investors from the highly-industrialised capitalist countries of the taxation which those less highly developed countries were entitled to enforce." ${ }^{2}$ The British delegate, meanwhile, was "in agreement with the Soviet Union and Polish delegations as to the desirability of winding up the Commission's activities, although for other reasons than those advanced by them," taking the view that the commission was not a useful forum. ${ }^{63}$ 


\section{Convergence on the OECD Model}

With work at the United Nations grinding to a halt, the Executive Committee of the ICC passed another resolution in 1954, identifying double taxation as a "serious obstacle" to trade and investment in Europe and calling on members of the OEEC to take steps to relieve it. ${ }^{64}$ The OEEC's secretary general was initially skeptical and noted that the ICC's proposal that the OEEC use the London Draft as the basis of its work was problematic because not all of its member and associate countries had endorsed it. "If an approach of this kind were to be adopted by the OEEC, therefore, it would be necessary for the Organisation to set up an expert body charged with the duty of attempting to produce a more acceptable draft."65

Soon after this, Switzerland and the Netherlands began to circulate proposals for a fiscal commission. A Dutch note in 1955 claimed that "the number and extent of problems relating to taxation has been steadily increasing, not only in the national field but also, and especially, in connection with the gradual intensification of international economic relations, in the international sphere." 66 It advocated work under the umbrella of the OEEC because it was consistent with the organization's mandate and because of the need to discuss in "a smaller circle than the United Nations." ${ }^{67}$ In December 1955 the Netherlands and Switzerland were joined by Germany, publishing a joint memorandum proposing the creation of an expert committee of "specially qualified high-ranking Government representatives," and in January 1956 an ad hoc committee was created to conduct a study into the matter. ${ }^{68}$ The ad hoc committee immediately recommended the creation of a full committee, citing "ample evidence that there are cases of double taxation which constitute obstacles to international trade and investment, and that action to remove these obstacles should be possible within a group of like-minded nations such as the members and associated countries of the OEEC."69

Within months, the new committee had begun to establish ways of working that are retained today, such as Working Parties delegated by the full committee to look in detail at each specific issue. It also began to elaborate the basis of the modern consensus on international tax. The result of these activities was the OECD Model Tax Convention on Income and Capital, the first complete draft of which was completed in $1963 .^{70}$

The OECD model treaty is the basis of over three thousand bilateral tax treaties. It sets out the areas in which states will negotiate, and articulates an ideal type of negotiated outcome, although in areas such as the particular maximum tax rates specified, bilateral negotiations may vary from this outcome. The OECD model also incorporates various explicit and implicit principles of the international tax regime. Two sets of standards are incorporated into the model treaty but also have a life outside it: the OECD's Transfer Pricing Guidelines and its information 
exchange standard. It is through the constant updating of the model and its associated guidance that the foundations of the international tax system evolve.

Critically, the OECD model bears a closer resemblance to the London Draft than the Mexico Draft, which is hardly surprising given that it was drafted by officials from many of the countries that had been present in London in 1946 but not in Mexico in 1943. In the touchstone areas of dividends, interest, and royalty payments, it eschews the Mexico Draft's exclusive conferring of taxing rights on the source country in favor of a shared taxing right over dividends and interest, and exclusive residence taxing rights over royalties. In these critical areas, which will reemerge in the case studies that follow, the conflict between source and residence countries, in which the Mexico Draft had been a lone voice for the former, was finally settled in favor of the latter through the decisive role of the OECD model. That said, as the report of the London conference makes clear, in many other areas with distributional consequences, even the Mexico Draft did not represent a radical shift from the League-OEEC-OECD consensus. ${ }^{71}$

The OECD model was not the last word for lower-income countries. In 1971 the Community of Andean Nations (CAN) of Bolivia, Chile, Colombia, Ecuador, and Peru signed Decision 40, which created a multilateral tax treaty between the CAN members, binding them to be "guided" by a standard agreement in tax treaty negotiations with members outside the community, and to consult with other members before signing such treaties. ${ }^{72}$ Decision 40 was a more radical departure than the Mexico model. Both the CAN multilateral treaty and the standard bilateral agreement gave exclusive taxing rights to the country of source for most types of income, creating a fundamental incompatibility with the OECD model treaty. The CAN model could not compete, however, with the preeminence of the OECD model. Natalia Quiñones observes that by the 2000s, "none of the ... Members had applied it in their treaties and it was a known fact that most OECD Member countries would not even consider the CAN Model as a reference for negotiating a bilateral treaty." 73 Other regional groupings, such as the Common Market of Eastern and Southern Africa (COMESA) and the Association of Southeast Asian Nations (ASEAN), have formulated their own models, but these do not diverge radically from the OECD model. ${ }^{74}$

The United Nations also took up tax treaty work again, with the creation of the Ad Hoc Group of Experts on Tax Treaties between Developed and Developing Countries, which met for the first time in 1969. This committee eventually formulated its own model, first published in 1980, but this was now closely based on the OECD model, accepting the core concepts on which it was based, and the broad settlement from the London model. By 2017, a fourth iteration of the UN model had been published, with a growing number of divergences from the OECD model. ${ }^{75}$ Some of these amendments explicitly reflect the committee's opinion 
regarding the appropriate balance between source and residence taxation. ${ }^{76}$ Lower-income and higher-income countries have disagreed over the status of the UN committee and its model treaties, with lower-income countries seeking to upgrade it to an intergovernmental body and agreement, and OECD members consistently opposing this. ${ }^{77}$ This disagreement reflects conflicting preferences about which body should play the main agenda-setting role.

\section{Consolidation and Expansion}

By any measure, the work of the OEEC/OECD Fiscal Committee has been a huge success. The committee's interim report in 1957 noted that its members had begun to "harmonise their views," which had "proved very useful during certain recent bilateral negotiations"; and by the time the OECD model was codified in 1963, around two hundred bilateral tax treaties had been signed. ${ }^{78}$ Indeed, the OEEC committee had recognized that other countries would likely be incentivized to follow Europe's lead, because of its "position in the world economy." 79 Most pairs of OECD members had a tax treaty by 1980 , and so the regime's expansion since then has been outward. There has been an exponential increase from the 1960s to the 1980s, driven by treaties between non-OECD members (figure 2.1). Consistently around 40 percent of tax treaties have been signed by lower-income countries, a number that far outstrips intra-OECD tax treaties. For the past three decades, growth has stabilized, with around one hundred new treaties concluded per year, on top of numerous renegotiations.

The success of the OECD's work is best indicated not by the number of treaties but by their content. Across the 39,600 relevant clauses in 2,200 treaties in my data set, all signed by at least one lower-income or emerging economy, OECD model provisions are used 61 percent of the time, while UN model provisions occur on the remaining 39 percent of occasions. Given that the UN model is explicitly designed for treaties signed between higher-income and lower-income countries, while the OECD model reflects purely the preferences of higher-income countries, this is a concerning outcome. Of course, because the OECD model reflects the preferences of OECD states, it partly reflects the power balance in negotiations: greater asymmetries in capabilities and investment positions lead to more OECD-type treaties ${ }^{80}$ But given that OECD model provisions also prevail in 46 percent of cases when neither signatory is an OECD member, the authoritative position of the OECD model is also a factor.

In addition to expanding in breadth, the OECD-centric international tax regime was also expanding in depth, becoming more legalized as countries attempted to 


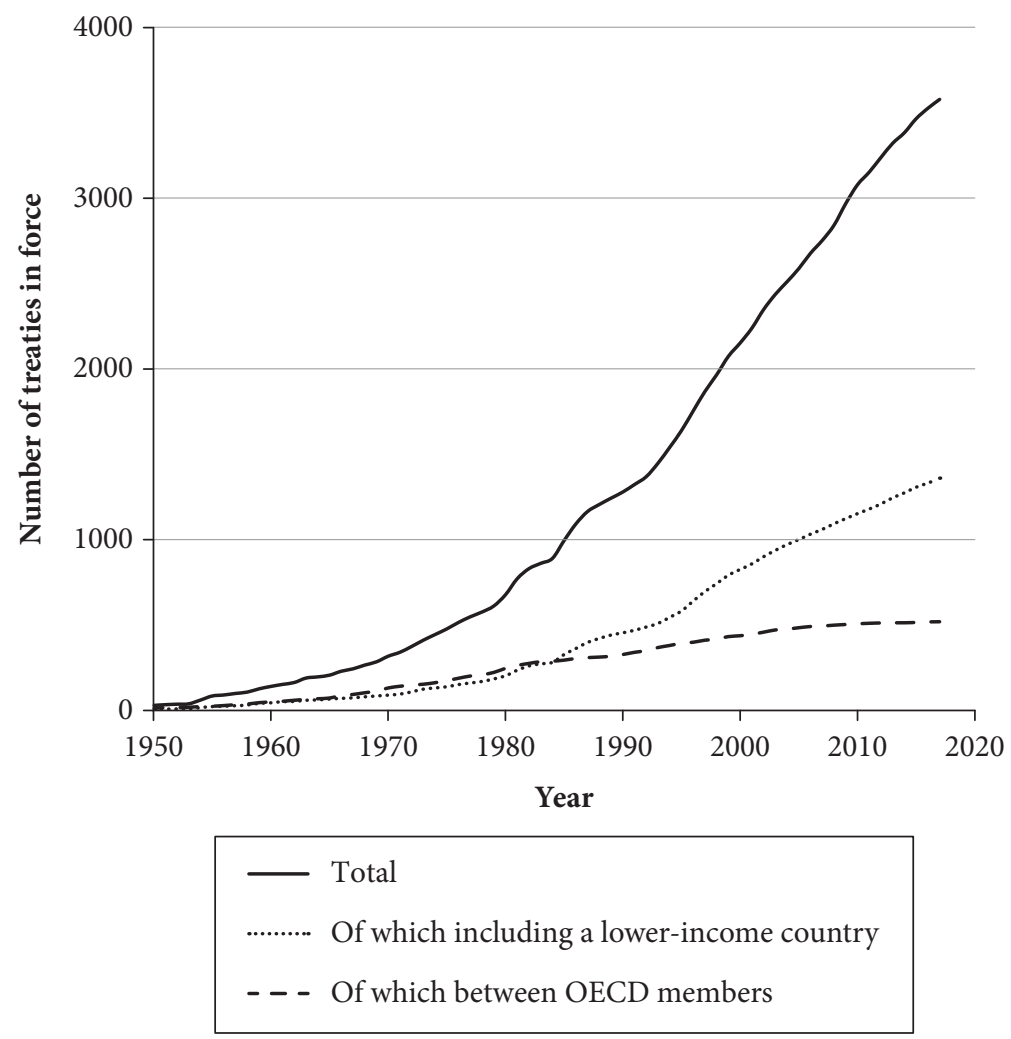

FIGURE 2.1. Growth in the number of tax treaties Source: IBFD, “IBFD Tax Research Platform," 2020, http://research.ibfd.org/.

spell out how the core principles would apply in new and more complex situations. The OECD model has been revised a dozen times, gradually increasing the specificity and complexity of the rules it entails, through the elaboration of a more detailed commentary. In 1979, the OECD published its report on transfer pricing, a document that spelled out how states should implement the approach to allocating profits to multinational companies that is found in article 9 of the model treaty. This was substantially revised in 1995, becoming the Transfer Pricing Guidelines, now almost as long as the model convention itself, but effectively an extension of the model treaty because they are referred to within its commentary. Multilateral tax instruments contain ten times as many words now as they did when countries first reached agreement on the OECD model. ${ }^{81} \mathrm{~A}$ further deepening of the regime is found through the creation of the mutual agreement procedure (MAP). This is a dispute settlement mechanism that taxpayers can trigger in order to force states to 
negotiate with each other if they disagree over the interpretation of the treaty. Initially characterized by its "antilegalistic" nature, ${ }^{82}$ the MAP has become more of an enforcement tool over time.

The OECD model bilateral treaty "represents the general consensus on international taxation." ${ }^{83}$ It is a "focal point ... defined as social conventions that are followed 'automatically' because they have become self-evident." ${ }^{14}$ As Genschel and Rixen set out, "The OECD Model Convention was embedded in a broad epistemic consensus on 'how to do double tax relief properly', which in turn reinforced its status as the self-evident reference point in matters of double tax relief once cross-border investments and capital mobility started to increase in the 1970s." ${ }^{" 15}$

The model, commentary, and guidelines have all gained an authoritative status that can be referred to by courts in the respective countries when seeking to interpret the treaty. ${ }^{86}$ That influence has extended, on occasion, to the interpretation of domestic legislation, rather than treaties ${ }^{87}$ With this in mind, OECD members can enter reservations on the model treaty, and since 1998 lower-income countries are also invited to formally set out their positions on the OECD model convention. The vast majority of lower-income countries' observations reflect a desire for greater source taxation, in keeping with the provisions of the UN model. Indeed, net-capital-importing countries enter more reservations or observations to the OECD model than net capital exporters. ${ }^{88}$

\section{The Problems of Tax Avoidance and Evasion}

Most literature on the politics of global tax governance focuses on the problems created when economic actors exploit weaknesses in the rules for international tax cooperation: tax avoidance, tax evasion, and the tax havens that help make them possible. While this book is focused on a different problem, it is worth considering the relationship between the source-residence tension and tax avoidance/evasion.

A state may claim the right to tax a person in principle, either because they are one of its residents or because they earn income within its borders. But there are practical constraints that may prevent it from exercising that right, and these constraints have helped shape the development of international tax norms to date. The two biggest are these: First, how can a state tax a person with sources of income in multiple countries if it cannot know whether the person has given an honest account of his or her global financial position? Second, how can a state force a foreign resident to pay tax on income earned within the state's borders if the 
foreign resident no longer has any income or assets in that state? The architects of the international tax regime in its earliest days were aware of this: the division of taxing rights between source and residence countries reflected practical realities as well as political settlements, ${ }^{89}$ the problem of tax evasion was as much a part of the remit of the League of Nations Fiscal Committee as double taxation, ${ }^{90}$ and tax treaties include instruments through which states share information with each other and cooperate to collect revenue from cross-border taxpayers. ${ }^{91}$

By the 1970s, however, tax avoidance and evasion had been intensified by a third problem, described by Ronen Palan as the "commercialisation of state sovereignty." 92 This refers to a jurisdiction offering residents of other countries the opportunity to adopt its nationality, attracting them with a preferential tax regime, without physically moving to that state. By becoming, on paper, a resident of this new jurisdiction, companies and wealthy individuals can exploit the international tax rules put in place by the states in which they operate, by which their taxing rights are curbed. In other instances, companies and individuals use the commercialized sovereignty of tax havens to conceal their wealth behind a veil of secrecy that cannot be penetrated by the tax authorities of the countries where they are actually present. Because this could not be resolved without either abandoning the key tenets of the international tax regime or introducing a coercive characteristic into its operation, the problem has proved particularly difficult to resolve. ${ }^{93}$

Tax treaties can include tools to help deal with such problems, but they are imperfect. Because they place constraints on signatories' ability to tax, they can also exacerbate it by creating opportunities for international tax avoidance. Here multinational taxpayers circumvent the intention of one country's tax laws by exploiting the differences between countries' tax systems and the constraints on their ability to tax international transactions as a result of tax treaties. ${ }^{94}$ Treaty shopping, in particular, uses the terms of tax treaties that divide up the tax base, combined with the advantageous laws of low-tax conduit jurisdictions such as the Netherlands and Mauritius, to obtain advantages not intended by (at least one of) the treaty signatories. ${ }^{95}$ Eduardo Baistrocchi has suggested that lower-income countries may deliberately avoid enforcing international tax rules as a form of tax competition, while Vincent Arel-Bundock argues that tax treaty shopping places pressure on countries to sign treaties. ${ }^{96}$

In the area of tax avoidance and evasion, higher-income and lower-income countries' interests are often aligned, since the winners from improved cooperation are states in which real economic activity takes place, while the "losers" from cooperation are tax havens and their users. Nonetheless, there are two differences. First, the asymmetrical nature of economic flows and enforcement capacities means that lower-income countries need a different form of cooperation than that 
of higher-income countries. For example, complex corporate tax structuring is a problem for higher-income countries, while lower-income countries often suffer from simpler structures that higher-income countries are better equipped to tackle. ${ }^{97}$ In contrast, as capital importers, lower-income countries need access to information on multinational investors that may be more readily available to the higher-income countries in which they are headquartered. ${ }^{98}$ The international tools of administrative cooperation formulated by higher-income countries may therefore not always meet the needs of lower-income countries. It is notable that the provision in tax treaties that obliges the capital-exporting state to collect tax on behalf of the capital importer, in cases where an investor from the former no longer has assets in the latter, is present in just 16 percent of treaties signed by lower-income and emerging economies, and much less than half of those signed since 2000, despite its presence in both the OECD and UN model treaties.

A second difference is that, while higher-income countries have the economic power to coerce tax havens into cooperating, lower-income countries that lack this coercive power must piggyback on initiatives designed by others or offer concessions during treaty negotiations. To obtain information from less cooperative tax havens, for example, some countries have found themselves obliged to sign a tax treaty that restricts their taxing rights and opens them up to treaty shopping. We can see, then, that the North-South axis colors this possibly existential challenge faced by the international tax regime.

\section{Conclusion}

In this chapter we traced the emergence of the multilateral institutions of tax cooperation, from the League of Nations in the 1920s-40s, via the United Nations, to the OEEC/OECD since the mid-1950s, supplemented since the 1970s by the UN again. The tension between capital-exporting and capital-importing nations, which is present within the OECD but much starker when lower-income countries are involved, has been present throughout. Hence, we see, broadly speaking, the same pattern in the interwar period as in the second half of the twentieth century. Higher-income countries reach an agreement among themselves that sets the parameters for future discussions in which lower-income countries can participate.

Higher-income countries have a greater shared interest in reaching agreement on a common set of international tax rules, and negotiations between them are less characterized by outright distributional conflict. This is because economic interactions among them are more intense and complex, and hence the potential for double taxation is more significant, while the economic relations are less one-sided. Negotiations between them in both eras took place primarily through 
technical experts, and it is notable that participants in the early work of both the League and the OEEC observed the importance of this epistemic consensus building. This shared understanding among participants, the foundation of their cooperation, was embodied in common language and principles that endure to this day, as well as in more transient formal agreements.

By the time that lower-income countries joined the discussions, the first-mover advantage of the higher-income countries was unassailable. At the League of Nations they entered into discussions after the contours of agreement had already been defined, while the UN committee that began work at the end of the 1960s was reduced to tweaking an OECD model treaty that had quickly attained hegemonic status. When lower-income countries asserted themselves more strongly, through the Mexico Draft in the 1940s and the UN Fiscal Commission in the 1950s, this merely provoked an unproductive stalemate that drove "like-minded" states to work through the OEEC. The CAN model also proved a nonstarter given its incompatibility with the OECD model. As chapter 8 will consider further, this historical record does not bode well for efforts by the OECD to open the institutions of multilateral cooperation to lower-income countries.

The chapters that follow will shift the focus from cooperation over multilateral soft law toward bilateral hard law. This is in keeping with the central puzzle of why lower-income countries have entered into bilateral agreements when the terms appear disadvantageous. It is also because multilateral tax institutions have been remarkably stable since the 1970s. Though the OECD and UN model treaties have been updated from time to time, these changes have been incremental adaptations and have hardly touched on the distributional questions at the heart of this book. The two main exceptions illustrate how stable the underlying settlement of the regime has been. A change to article 7 of the OECD model in 2007 that conferred greater taxing rights on the home countries of multinational firms has yet to gain widespread acceptance. At the UN, meanwhile, the inclusion of a new article 12A in the 2017 edition of the UN model permits the imposition of a withholding tax on technical service fee payments. This can be seen as a shift toward capital-importing countries, but it is hardly revolutionary: it was already under discussion at the UN in the 1970s and has become common, albeit in a minority of treaties signed by lower-income countries. Countries do have some autonomy to differ from the formal rules set out in the models, yet, as the subsequent chapters emphasize, it is the ideational consensus about tax treaties that exerts the most powerful conditioning effect. 